\title{
Problems and Countermeasures in the Training of International Trade Professionals in Higher Vocational Colleges
}

\author{
Peng Li \\ Xuchang vocational and technical college, 461000, China
}

Keywords: vocational colleges; international trade; professional talents

\begin{abstract}
On November 20th, 2001, China has accessed to the "WTO ", nearly 17 years. During this period, China's economy has continued to develop at medium and high speed, and "China's speed" has made the world wonder. In 2010, China's economy size is larger than Japan, leapt to the world's second largest economy, China's economy has made remarkable achievements, in the final analysis from the promotion of high-quality talent, for which China's economy continue to maintain the leading level in the world. It is necessary to increase the training of international trade professionals, this paper studys on the vocational colleges of international trade professionals training problems and countermeasures.
\end{abstract}

\section{Introduction}

Higher vocational education is an important part of China's education, it is to cultivate professional technical talents for the purpose of education, bear the mission of transporting professionals to the community. Most of the international trade majors are opened higher vocational colleges, in the economic class of vocational colleges, international economy and trade is a compulsory course, it is the basic course,the key course. In the actual teaching the effect of international practice coursesis not ideal, there are still some problems need to be solved, such as students do not understand the teacher's lectures, teachers do not know the degree of mastery knowledge, professional teaching is boring, students lost interest and other issues. The main reason for the emergence of these problems is that teachers can not understand the characteristics of vocational students, compared with college students, the theoretical level vocational students is poor, they are more difficult to understand some of the concept of strong abstract theoretical knowledge, but these basic theoretical knowledge is the focus of international trade professional teaching, teachers can not learn from the characteristics of students, with theoretical knowledge to interpret the theoretical knowledge, it can only let students deviate from the teaching focus, that can not be mentioned in the classroom teaching, the emergence of the status quo is more students are confused to the knowledge.

\section{Characteristics of International Trade Specialty in Higher Vocational Education}

In the higher vocational education system, the orientation of colleges and universities should be different from the comprehensive research universities and secondary vocational education schools. There are two essential characteristics of higher vocational education: one is " high ", that is, higher vocational education is part of higher education as a special kind of higher education ; one is the " job ", that is, vocational education needs to emphasize the practicality and relevance of professional and technical [1]. Higher vocational education international trade is different from the comprehensive research university, focusing on cultivating students ' international trade professional theory and knowledge of practical operation ability. Around the purpose of education, vocational colleges in the professional teaching can not put the main energy of the full investment of the transmission of theoretical knowledge, they also need to focus on the practice of knowledge which is applied to the skills as an important assessment indicators to assess students ' international trade. The level of mastery of professional knowledge can not blindly tap the depth of the concept of international trade professional, can not practice the application of teaching into theoretical research teaching, in order to make professional knowledge " smooth landing ", the theoretical content of professional content only need students to master the foundation, that requires students 
can answer " what ", " why ", " how " on the line .Through professional study, students should have professional skills of the international trade, they need to understand the English trade agreement, independent customs declaration,inspection, insurance and related procedures, they need to communicate with foreign banks and foreign enterprises and achieve the objectives of cooperation and so on, higher vocational international trade professional requires students have a good control of English, because English is the basis of international trade communication, so the international trade professional teachers not only need to teach international trade-related knowledge but also need to focus on the students trade English training, as much as possible to create a trade situation, so that students can master trade English, which is the characteristics of international trade disciplines.

\section{Problems in the Training of International Trade Professionals}

\subsection{Cognitive Ability of Vocational Students Generally is Low}

Higher vocational students generally are college students whose college entrance examination achievement are not ideal, compared with undergraduate students their basic knowledge is weak, the homework ability and understanding is also poor [2]. Students' basic knowledge is weak, it will directly lead to that their cognitive ability is difficult to improve, caused a certain impact to the teacher classroom teaching. If in accordance with the traditional teaching methods, teachers choose the method of using theory to explain the theory, it can only let students feel the theory is more complex, and if teach with more cases, students will focus on cases. Teachers must use the appropriate teaching methods to reveal the international trade theory of knowledge content behinds on the cases, in the teaching method slightly discomfort, which will allow students to stay in the case itself, even they understand the knowledge and content of this case, they cannot flexibly reflects the migration of knowledge to other practical applications, the students are not generally aware of the current situation, so that international trade teachers in the classroom teaching are getting into a "dilemma" situation.

\subsection{Blurred Goal of Cultivating the Target, Leading to the Imbalance of Educational Effect}

China's vocational colleges and universities exists the problem that the goal of the international trade professional training objectives is not accurate enough, the regional capacity of foreign trade positions are not convergence and other issues, resulting that the training of talent is out of touch with social needs, foreign trade enterprises are difficult to hire worker, students are difficulty to find jobs [3]. The goal of cultivating the target is ambiguous, which will make the vocational school deviate from the actual demand of the society in the process of teaching students according to the individuality, which will lead to the lower educational and the loss of the educational effect. The fuzzy on the positioning of personnel training of vocational colleges and universities is directly response in the curriculum of resource allocation, they wrongly believe that the theoretical knowledge of the universal practical significance, so strengthen the theoretical teaching, and set to elective courses for the practical application of more frequent foreign trade agreement, foreign trade correspondence, they are not included in the assessment system for students, the positioning fuzzy lead to serious "cart before the horse", "overwhelming", from the goal of the application of knowledge and practice, so that the educational effect loss of balance, there is unreasonable roll.

\subsection{Modeled Teaching Methods, Cannot Bring Students' Interest in Learning}

In the teaching the international trade professional teachers are accustomed to follow the experience step by step to promote teaching, they will prepare lessons carefully, determine the teaching objectives, develop a reasonable teaching plan, in the classroom teaching, according to their original plan, step by step, change the classroom teaching into a personal "talk show" program, though they are working hard, seriously, at the final students did not understand, and they will blame the poor ability of students. The inevitable phenomenon is caused by the teaching method is too paradigm, teachers do not attach importance to the significance of the generation of teaching, 
students can not mention the interest, teachers do not know how to communicate with students, only makes the teach content is farther to students.

\subsection{Lack of Teachers who are "Double Division Double JOB" of Education Professionals}

Most of the professional teachers of international trade of higher vocational colleges are the theoretical talents that are graduating from colleges and universities. They have rich theoretical experience, good at doing research and teaching research, and few teachers have the teaching conditions of " double division double job ". The overall team practice level of the teachers is not high, in the actual teaching it is difficult to really do the combination of theory and practice.

\section{Suggestions of the Cultivation of International Trade Professionals in Higher Vocational Colleges}

\subsection{Determine Clear Goal of Personnel Training Based on Market Demand-Oriented}

The goal of personnel training in higher vocational colleges should be closely related to the needs of society and cultivate international trade professionals that can help China's economic development and social progress. Higher vocational colleges for the international trade market should always maintain a high degree of attention, pay attention to changes in the market, flexibly adjust teaching strategies according to market changes, consciously put the idea of advancing with the times . In order to improve the employment rate of the students, the vocational colleges need to keep abreast of the employment standards of the foreign trade enterprises and the various needs of the talents, market-oriented, clear the talent training objectives, improve the student's employment rate and enhance the students ' market competitiveness .

\subsection{Construction of the Dual Point of Teaching system Combined Professional Courses with English Courses}

International trade courses need to avoid too theoretical, can not blindly enlarge the theory and reduce the practice and application, need to take the practical application as the goal, carry out the basic theoretical courses. In the curriculum configuration, we should pay attention to the practical application of the content, such as the formulation of foreign letters, to consider and formulate the import and export trade agreement and so on, we cannot pursue the theoretical macro-meaning too much, while applying but found nothing less.

At the same time, the international trade profession should pay more attention to the role of business English, the basis of communication with English, whether it is textual materials or foreign exchange it requires professional English level to support the daily work, so teachers in teaching need to provide bilingual teaching possibly. In the classroom teaching more English, cultivate students ' sense of language, analog communication situation, improve the students ' level of business English .

\subsection{Create a "Double Division Double Job" Brand Team, Improve the Level of Education}

Since the international trade profession is an applied course, then the professional teacher must have a certain practical experience, they can really do the combination of theory and practice, both master the level of professional education and teaching, but also has professional operation skills , so that they become a " double division double job " type of professionals, schools need to connect with business, give more practice opportunities for teachers, so as to improve level of practice of teachers .

\section{Conclusion:}

International trade related to China's import and export trade quality, so it is essential for the cultivation of talent. Vocational colleges should have a clear goal of personnel training, market demand-oriented rational teaching of international trade students, and constantly improve the teacher's "double division double job" teaching ability, so as to ensure that students generally 
improve the professional level.

\section{References}

[1] Huang Cancan, Higher Vocational Education Reform of International Trade [J]. Commercial Economics, 2012 (8): 36-37

[2] $\mathrm{Wu}$ Jianjun, on the current vocational colleges in the international trade professional teaching problems [J], speed reading Xun, 2015 (9)

[3] Zheng Junrui , Li Hui, vocational colleges international trade professional personnel training problems and countermeasures [J]. Education Exploration .2013 (8): 107-108 